fetal, avaliando-se o osso nasal, o perfil facial, o maxilar superior, o triângulo retronasal e o septo nasal, foi diagnosticada Trissomia 21. Devido às malformações fetais e à idade materna avançada, foi confirmado o cariótipo fetal e, uma vez realizado o aconselhamento genético, após consentimento informado, foi decidida a interrupção médica da gravidez.

Discussão e conclusões: Na trissomia 21 a hipoplasia nasal e maxilar constituem anomalias faciais expectáveis. A avaliação do crescimento do osso e septo nasal, ao longo da gestação, possibilita o despiste de alterações, nomeadamente de aneuploidias (Corte Real I et al; 2016). Recentemente, Adiego et al. (2014), descreveram a análise do triângulo retronasal, como indicador da avaliação do osso nasal. Já em 2004, Cicero et al. reportaram que a maxila superior curta seria indicador de Trissomia 21. Mihailovic et al. (2012) descreveram associação ecográfica entre a ausência do vómer e Trissomia 21. As estruturas ultrassonográficas faciais descritas poderão, assim, ser utilizadas como marcadores ultrassonográficos precoces no rastreio da Trissomia 21, tal como o caso clínico apresentado comprova. É de suma importância que o Médico Dentista conheça os parâmetros de avaliação ultrassonográfica facial fetal, no diagnóstico pré-natal precoce desta patologia, de modo a planear intervenções médico-dentárias futuras.

http://doi.org/10.24873/j.rpemd.2018.11.243

\section{\#003 Goma Sifilítica, Relato de um Caso Clínico}

Cláudia Mata*, Sara Fontes, Paulo Palmela,

Nuno Santos, Francisco Salvado

\section{Centro Hospitalar Lisboa Norte EPE}

Introdução: A Sífilis é uma doença sexualmente transmissível, causada pela bactéria Treponema Pallidum. Os sintomas e sinais clínicos podem ser variáveis, consoante o estadio em que se manifestam: Primário, Secundário, Latente ou Terciário. Existem 3 categorias gerais de Sífilis Terciária: Goma Sifilítica, Sífilis Cardiovascular e Neurosífilis.

Descrição do caso clínico: Doente de 63 anos, caucasiano, antecedentes de Diabetes Mellitus Tipo II não insulino-tratada e fumador (75 UMA) encaminhado à consulta de Estomatologia por aparecimento em 15 dias de 2 úlceras do palato duro ligeiramente dolorosas, simétricas, com fundo nacarado e cheiro fétido, com atingimento ósseo. Restante história irrelevante. As hipóteses de diagnóstico colocadas foram Sobreinfecção Bacteriana de Úlceras Traumáticas, Sialometaplasia Necrotisante, Sífilis, Granulomatose de Wegener, Carcinoma pavimento-celular; Linfoma de células T/NK. Pela suspeita de sobreinfecção bacteriana foi tratado empiricamente com Amoxicilina $1 \mathrm{~g} 8 / 8 \mathrm{~h}$ durante 4 semanas, com cicatrização progressiva.O diagnóstico definitivo de Sífilis foi dado pela suspeita clínica e positividade na avaliação serológica. As biópsias do fundo das úlceras mostraram necrose e colonização por Aspergillus. De acordo com as normas internacionais, o doente foi tratado com Penicilina G Benzatínica parentérica, com resolução total das manifestações clínicas, a aguardar reavaliação serológica.

Discussão e conclusões: Cerca de 1/3 dos doentes com Sífilis não tratada desenvolvem complicações tardias-16\% Goma
Sifilítica, 10\% Sífilis Cardiovascular, 6\% Neurosífilis. Embora não houvesse história anterior de Infecção por Sífilis, as lesões eram altamente sugestivas de Goma Sifílica em doente não imunossuprimido. É uma lesão com aparecimento tardio, que se apresenta como um (ou mais) nódulo ou úlcera granulomatosa que pode acometer tanto os tecidos moles como osso. Afeta sobretudo o palato, onde frequentemente provoca perfuração, podendo estabelecer uma comunicação entre a cavidade oral e nasal. Sendo prontamente identificada resolve totalmente com altas doses de penicilina. As manifestações orais em geral são incomuns e podem representar um desafio diagnóstico devido à variedade de apresentações clínicas. Conhecida como a grande imitadora, por poder mimetizar outras patologias, a Sífilis deve ser considerada como hipótese de diagnóstico na avaliação das lesões orais quando existe um elevado grau de suspeição, mesmo na ausência de história sugestiva.

http://doi.org/10.24873/j.rpemd.2018.11.244

\section{\#004 Tratamento endodôntico e bloqueio de abertura mandibular - a propósito de um caso clínico}

Angela Leal*, Vera Cheroux, Eduardo Januzzi, André Mariz de Almeida

Prática Clínica Privada, Instituto Universitário Egas Moniz

Introdução: As disfunções temporomandibulares são um conjunto de condições que afetam a articulação temporomandibular e músculos associados negativamente. A etiologia é multifactorial e o diagnóstico e tratamento devem ser sempre abordados multidisciplinarmente. As desordens musculares são o diagnóstico mais comum, onde encontramos a miosite, definida como uma inflamação de músculos, caracterizadas por edema, inibição da função muscular, alteração da sensibilidade e dor. A dor odontotogénica é a principal dor orofacial e por vezes cursa com a disfunção temporomandibular.

Descrição do caso clínico: Paciente com 47 anos, sexo feminino, recorre a consulta com queixas de bloqueio de abertura mandibular após tratamento endodôntico, no dente 48, há cerca de 2 semanas, por necrose pulpar, e consequente formação de processo infeccioso com processo periapical e edema na hemiface direita. Apresentava uma abertura máxima assistida de $11 \mathrm{~mm}$, endfeel duro, padrão de abertura com deflexão à direita, sem ruídos articulares nem dor à palpação das ATM's. Já na palpação muscular apresentava dor em vários músculos mastigatórios. Após a realização de radiografia periapical iniciámos o diagnóstico diferencial com recurso à aplicação de crioterapia, na zona do masséter e temporal e consequentes bloqueios anestésicos musculares, com aumento sucessivo de abertura mandibular. Finalmente foi realizado o bloqueio anestésico infiltrativo na região do 48 o que nos levou de uma abertura intermédia de 24,6 para $35 \mathrm{~mm}$. O diagnóstico final é miosite, com mio-espamo do músculo masséter secundária a causa odontogénica do 48. A gestão do caso deve ser feita com Fisioterapia para relaxamento da musculatura mastigatória e restaurar a qualidade e quantidade dos movimentos mandibulares. 